\title{
Rice Seed Production Under Conditions of Salinity Stres
}

\section{Fabio Schaun Harter ${ }^{1}$ Leticia dos Santos Holbig Harter $^{2^{*}} \odot$ Geri Eduardo Meneghello $^{3}$}

\author{
${ }^{1}$ Universidade Federal de Pelotas (UFPel), Pelotas, RS, Brasil. \\ ${ }^{2}$ Curso de Agronomia, Sociedade Educacional Três de Maio (SETREM), 98910-000, Três de Maio, RS, Brasil. E-mail: 1sholbig@yahoo.com.br. \\ ${ }^{*}$ Corresponding author. \\ ${ }^{3}$ Programa de Pós-graduação em Ciência e Tecnologia de Sementes, Faculdade de Agronomia Eliseu Maciel (FAEM), Universidade Federal \\ de Pelotas (UFPel), Pelotas, RS, Brasil.
}

\begin{abstract}
In the present study, the objective was to evaluate the production and quality of rice seeds of four cultivars under conditions of saline stress caused by irrigation water. The work was carried out at the EliseuMaciel Agronomy College of the Universidade Federal de Pelotas, with four rice cultivars, IRGA 417, Avaxi CL, Inov CL and IAS 12-9 (Formosa). In the experiment, the following saline concentrations were used: $0 ; 12.5 ; 25 ; 37.5 ; 50 ; 75$ and 100mM. After completing the crop cycle, the following agronomic characteristics were evaluated in each of the plants: number of panicles, total weight of panicles, percentage of full seeds, percentage of seedlings and weight of a thousand seeds. The physiological quality of the seeds harvested from the plants maintained under conditions of salinity stress was evaluated by germination and first count tests. Saline stress reduced the productivity and physiological quality of rice seeds, with different responses from the four cultivars used.

Key words: Oryza sativa L., saline stress, physiological quality, agronomic characteristic.
\end{abstract}

Produção de sementes de arroz em condições de estresse por salinidade

RESUMO: Na presente pesquisa o objetivo foi de avaliar a produção e a qualidade de sementes de arroz de quatro cultivares em condições de estresse salino causado pela água de irrigação. O trabalho foi realizado na Faculdade de Agronomia Eliseu Maciel da Universidade Federal de Pelotas, com quatro cultivares de arroz: IRGA 417, Avaxi CL, Inov CL e IAS 12-9 (Formosa). Para o experimento utilizou-se as seguintes concentrações de salinidade: 0,0, 12,5, 25, 37,5, 50, 75 e 100mM. Após completar o ciclo da cultura, avaliaram-se as seguintes características agronômicas em cada uma das plantas: número e peso total das panículas, porcentagem de sementes cheias, chochas e peso de mil sementes. A qualidade fisiológica das sementes colhidas das plantas mantidas em condições de estresse por salinidade foi avaliada pelos testes de germinação e de primeira contagem. O estresse salino reduz a produtividade e a qualidade de sementes de arroz, com respostas diferenciadas dos cultivares quando submetidos a condições de estresse salino.

Palavras-chave: Oryza sativa L, estresse salino, qualidade fisiológica, característica agronômica.

\section{INTRODUCTION}

The area of irrigated rice cultivation in Rio Grande do Sul is approximately 1.1 million hectares, accounting for about $60 \%$ of the national production, with a daily average of $7.5 \mathrm{t}$ ha-1, while the average production of Brazil is 5.8t ha-1 (CONAB, 2016).

This productivity is obtained despite the biotic and abiotic stresses that the crop faces, with salinity being one of the most important and affecting several aspects of the physiology and biochemistry of plants, with the consequent reduction of yields. High exogenous salt concentration could affect the seed germination, causing water deficit, imbalance in the cells, osmotic toxicity and osmotic stress (KHAN \& PANDA, 2008).
Plant tolerance to salinity varies according to species, phenological cycle and stage of development. Some species, such as sorghum, maize, beans and wheat, are less affected during the initial phase of their cycle (MAAS et al., 1986). However, other species are quite sensitive during flowering and fruiting (DEUNER et al., 2011).

Rice is considered to be tolerant to salinity during germination, but very sensitive at the seedling stage, since tolerance increases progressively during tillering, until the species becomes sensitive again at flowering and tolerant during the maturation period of the grain (SANTIAGO et al., 2013). Carmona et al. (2011) reported that the tolerance of rice to salinity varies according to the stage of development of the 
crop, with the phases of seedling and flowering being critical. At levels above those that are tolerable, water salinity causes losses in crop establishment, reduction of tillering, chlorosis and death of leaves, and diminution of plant height, in addition to increasing the sterility of spikelets and number of non-productive tillers.

The most common symptoms caused by salinity are the reduction of growth and the occurrence of whitening at the leaf tips with consequent death, and, if the plant is close to the reproduction phase, the occurrence of white and empty leaves in the flowering period (SANTIAGO et al., 2013).

In the case of crops destined for seed production that are grown under conditions of salinity stress, the effects may be to extend the next generation, since the mother plant may not be in a condition to allocate the necessary amount of reserves to the seed, generating ununiform plants. Plant responses to salinity are often accompanied by morphological and anatomical changes, such as reduction of growth and leaf area, which are mainly associated with the reduction of turgor pressure, which interferes with the processes of stretching and cell division (TAIZ \& ZEIGER, 2013).

Considering the above, the objective of the present study was to evaluate the production and quality of rice seeds of four cultivars under conditions of saline stress generated by irrigation water.

\section{MATERIAL AND METHODS}

The study was conducted at the Faculdade de Agronomia Eliseu Maciel of the Universidade Federal de Pelotas (FAEM/UFPel) using four rice cultivars, IRGA 417, Avaxi CL, Inov CL and IAS 12-9 (Formosa).

The following concentrations of salinity were used in the experiment: zero salinity, $25 \mathrm{mM}$ (1.46g NaCl L-1), 50mM (2.94g NaCl L-1), $75 \mathrm{mM}$ (4.39g NaCl L-1) and 100mM (5.85g NaCl L-1).

Over time, seedlings irrigated with the highest concentrations of $\mathrm{NaCl}$ were foundleaves scorched tips and some plants were almost dead. To verify the best concentrations and to go on with it, a transplant was performed to obtain a higher number of concentrations and normal seedlings, which resisted the treatments and to complete the crop cycle. As a consequence the salinity concentrations were as follows: zero salinity; $12.5 \quad(0.73 \mathrm{~g}$ L-1NaCl); 25 (1.46g NaCl L-1); 37.5 (2.19g NaCl $\mathrm{L}-1) ; 50$ (2.93g of $\mathrm{L}-1 \mathrm{NaCl}) ; 75$ (4.39g L-1NaCl) and $100 \mathrm{mM}(5.85 \mathrm{~g} \mathrm{~L}-1 \mathrm{NaCl})$.
The sowing of the cultivars was carried out in buckets containing 10kg of soil (hydromorphic eutrophic solodicplanosol type), with fertility adjusted according to soil analysis results. Eight seeds were sown per bucket, and through the process it was left just one seedling to be conducted throughout the crop cycle. The water levelwas maintained throughout the crop cycle at the specified concentrations of saline used in the experiment.

During the crop cycle, six applications of urea were used, even when symptoms of plant deficiency were observed. For each application, $45 \mathrm{~kg}$ of urea per hectare was used, which corresponded to $1.6 \mathrm{~g}$ per plant or bucket. Two applications of Nativo ${ }^{\circledR}$ fungicide (Trifloxystrobin and Tebuconazole) and two of Pirephos ${ }^{\circledR}$ insecticides (esfenvalerate + fenitrothion) and Karate Zeon $50 \mathrm{CS}^{\circledR}$ (lambdacyhalothrin) were also used to control pests.

The panicles were harvested manually with scissors, and the panicles from each experimental unit were packed in a Kraft paper bag. At the time of harvest, the seeds had a water content in $20 \%$, so that after harvesting they were dried in a steady dryer until reaching approximately $13 \%$ moisture.

After completing the crop cycle, several agronomic characteristics were evaluated in each of the plant. The number of panicles (NP) was evaluated at harvesting, involving all the panicles per plant that had formed seeds, both empty and full. Panicle total weight (PTP) was determined after drying, when the panicles were threshed manually, and was the total weight of the seeds produced. Subsequently, the samples were passed through a seed blower to separate the full seeds and empty seeds. The percentage of full seeds (S) was calculated from the total seeds. Percentage of empty seeds (C) was calculated from the total weight of seeds. Weight of one thousand seeds (PMS) was determined from eight sub-samples of 100 seeds, which were counted and weighed and the result calculated by multiplying the average weight obtained from the subsamples by 10 (BRASIL, 2009).

The physiological quality of the seeds harvested from the plants maintained under conditions of salinity stress was evaluated by the germination test and first germination count ( $\left.1^{\mathrm{a} T G}\right)$. The germination test (TG) involved four sub-samples of 50 seeds per experimental unit; these were seeded onto germitest paper with distilled water. The seeds were placed in the germinator at a temperature of $25 \pm 2{ }^{\circ} \mathrm{C}$ and the counts were carried out at seven and fourteen days after sowing. The results were presented as the arithmetic mean of the four replicates, 
in whole percentage numbers (BRASIL, 2009). The first germination count (1TG) was performed in conjunction with the germination test, and consisted of recording the percentage of normal seedlings verified in the first germination test count, seven days after sowing (NAKAGAWA, 1999), and the results expressed as a percentage of normal seedlings.

For the variables relating to agronomic characteristics, a randomised block design with six replications was used, each bucket being an experimental unit. In the case of variables concerning physiological quality, a completely randomised design with four replications was used. In both cases a $4 \times 7$ factorial scheme was used, cultivars $(4$ levels $) \times$ saline concentration $(7$ levels). Statistical analysis was performed using the Winstat statistical program (MACHADO, 2002). The mean values were submitted to analysis of variance, whose assumptions had been previously tested, and, being significant, a mean comparison test was performed.

\section{RESULTS AND DISCUSSION}

'Only those plants exposed to zero salinity levels and $12.5 \mathrm{mM}$ produced seeds. With exposure to intermediate concentrations $(25,37.5$ and $50 \mathrm{mM})$ plants survived but did not reach the reproductive stage. All plants subjected to salinity levels of 75 and $100 \mathrm{mM}$ died.

With regard to the number of panicles per plant (Table 1), there was no significant difference between the control (without salinity stress) and the concentration of $12.5 \mathrm{mM}$ with all cultivars evaluated.
In the study of Rodrigues et al. (2005), the authors evaluated the effect of salinity of irrigation water on growth and rice production and found that there was a decrease in the number of panicles per plant with increased salinity. Excess salinity consequently causes water deficit, and when it occurs in the reproductive phase, especially during grain filling, has a direct effect on productivity (KALAMIAN et al., 2006).

Reduction in the productivity on the basis of salinity stress could be occur, and the principal factor is the reduction of photosynthetic capacity (SULTANA et al., 1999) and a decrease in the accumulation of photoassimilates in the grain (ASCH et al., 2000). During the reproductive period in rice, salinity causes morphological variations similar to other environmental stresses, which cause inhibition of the growth of plant structures, such as the degeneration of primary, secondary and panicle spikelets (CUI et al., 1995). In these circumstances, spikelet sterility is a characteristic parameter that correlates significantly with grain yield of the crop (KATHUN \& FLOWERS, 1995).

In the case of total panicle weight (Table 1), in all cultivars tested the control treatment was superior, in the Inov CL cultivar the total weight of panicles was $85 \%$ higher at a $\mathrm{NaCl}$ concentration of $0 \mathrm{mM}$. In sunflowers cultivated under conditions of saline stress, Travassos et al. (2011) observed a decrease in the number and mass of achenes with an increase in the salinity levels in irrigation water. Similarly, Soares et al. (2015) observed reduction in shoot growth of soybean seedlings subjected to $\mathrm{NaCl}$ stress. In cucumber plants, salinity of irrigation water adversely

Table 1 - Number of panicles (NP), total panicle weight (PTP), percentage of full seeds (S), percentage of empty seeds (C) and weight of one thousand seeds (PMS) in rice produced under conditions of saline stress at saline concentrations 0 and $12.5 \mathrm{mM}$ using the cultivars IRGA 417, Avaxi CL, Inov CL and IAS 12-9 (Formosa).

\begin{tabular}{|c|c|c|c|c|c|c|c|c|c|c|}
\hline \multirow{3}{*}{ Cultivars } & \multicolumn{2}{|c|}{ NP (und) } & \multicolumn{2}{|c|}{ PTP $(g)$} & \multicolumn{2}{|c|}{$\mathrm{S}(\%)$} & \multicolumn{2}{|c|}{$\mathrm{C}(\%)$} & \multicolumn{2}{|c|}{ PMS (g) } \\
\hline & \multicolumn{10}{|c|}{ 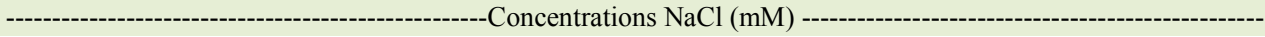 } \\
\hline & 0 & 12,5 & 0 & 12,5 & 0 & 12,5 & 0 & 12,5 & 0 & 12,5 \\
\hline IRGA 417 & $61^{*}$ & 58 & $97,80 \mathrm{~A}$ & $28,32 \mathrm{~B}$ & $97 \mathrm{~A}$ & $72 B$ & $3 B$ & $28 \mathrm{~A}$ & $22,14 \mathrm{~A}$ & $17,12 \mathrm{~A}$ \\
\hline Avaxi CL & 54 & 59 & $104,19 \mathrm{~A}$ & $21,74 \mathrm{~B}$ & $97 \mathrm{~A}$ & $53 \mathrm{~B}$ & $3 \mathrm{~B}$ & $47 \mathrm{~A}$ & $22,59 \mathrm{~A}$ & $14,55 \mathrm{~B}$ \\
\hline Inov CL & 44 & 38 & $81,43 \mathrm{~A}$ & $11,86 \mathrm{~B}$ & $95 \mathrm{~A}$ & $40 \mathrm{~B}$ & $5 B$ & $60 \mathrm{~A}$ & $23,52 \mathrm{~A}$ & $15,69 \mathrm{~B}$ \\
\hline IAS 12-9 (Formosa) & 48 & 49 & $97,63 \mathrm{~A}$ & $22,26 \mathrm{~B}$ & $99 \mathrm{~A}$ & $75 \mathrm{~B}$ & $1 \mathrm{~B}$ & $25 \mathrm{~A}$ & $22,77 \mathrm{~A}$ & $13,34 \mathrm{~B}$ \\
\hline $\mathrm{CV}(\%)$ & \multicolumn{2}{|c|}{16,52} & \multicolumn{2}{|c|}{27,32} & \multicolumn{2}{|c|}{11,87} & \multicolumn{2}{|c|}{43,32} & \multicolumn{2}{|c|}{10,01} \\
\hline
\end{tabular}

Mean values for each variable followed by the same letter in the line did not differ between each other using the Tukey test, at a $5 \%$ level of significance. ${ }^{*}$ Values not significant for the analysed variables. 
affected the emergence, growth and accumulation of dry mass (ALBUQUERQUE et al., 2016).

In order to evaluate the influence of salinity levels on irrigation water at different stages of rice development, Fraga et al. (2010) concluded that the number of panicles, grains per panicle, weight of a thousand grains, sterility of spikelets and grain production were negatively altered with increasing salinity at all stages of crop development.

With regard to the percentage of full seeds (Table 1), there was no statistical difference between cultivars; values were higher than $95 \%$ in plants produced without saline stress, while in plants grown under conditions of salinity, although this percentage did not differ significantly, absolute values for the percentage of filled seeds ranged from 40 to $75 \%$. Consequently, the percentage of seedlings (Table 1) was higher at the concentration of $12.5 \mathrm{mM}$, and there was no statistical difference between the cultivars. In an investigation of rice cultivation, Carmona (2011) observed that, during the reproductive and seedling periods, salinity of irrigation water can cause damage, such as reduced tillering, sterility of spikelets and death of plants.

With regard to the weight of one thousand seeds (Table 1), at a zero salinity level with all cultivars the values were higher and did not differ significantly. However, at a salinity level of $12.5 \mathrm{mM}$, only the seeds of the cultivar IRGA 417 showed a greater weight of one thousand seeds. The reduction in the weight of a thousand grains/seeds under conditions of saline stress was also demonstrated in studies of rice seeds (RODRIGUES et al., 2005, LEMES et al., 2010) castor bean (Silva et al., 2008), peanut (CORREIA et al., 2009), sunflower (TRAVASSOS et al., 2011) and okra (SOUZA et al., 2014).

For the seeds produced under conditions of saline stress with a concentration of $12.5 \mathrm{mM}$, the physiological quality of seeds from all cultivars (Table 2) was lower in the two variables tested (First germination account, and germination) than in the control treatment $(0 \mathrm{mM})$.

These results corroborate those obtained by Souza et al. (2014) with okra seeds. They observed that there was superior germination in the seeds produced without salt stress compared to the other saline stresses, confirming that increased salinity negatively affected the physiological quality of the seeds. However, Lemes et al. (2013) did not observe reduced physiological quality in seeds produced under saline conditions.

The data from first germination count and germination tests (Table 2) showed no differences between the seeds produced by the different cultivars. At a saline concentration of $12.5 \mathrm{mM}$, seeds from the cultivar Avaxi $\mathrm{Cl}$ showed the best physiological quality and these differed from the other cultivars, whereas seeds from the cultivar IAS 12-9 (Formosa) had the poorest physiological quality.

The results showed that the highest sensitivity to saline stress occurred in the cultivar IAS 12-9 (Formosa) in relation to the other cultivars.

\section{CONCLUSION}

Saline stress reduced the productivity and physiological quality of rice seeds, with different responses from the four cultivars used.

Table 2 - Physiological quality of rice seeds from the cultivars IRGA 417, Avaxi CL, Inov CL and IAS 12-9 (Formosa), produced with different concentrations of $\mathrm{NaCl}$, evaluated by first count $\left(1^{\mathrm{a}} \mathrm{TG}\right)$ and germination (TG) tests.

\begin{tabular}{|c|c|c|c|c|}
\hline \multirow{3}{*}{ CULTIVARS } & \multicolumn{2}{|c|}{ 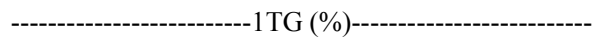 } & \multicolumn{2}{|c|}{ 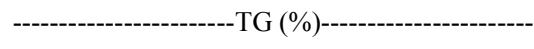 } \\
\hline & -- & ---Conc & M)----- & --- \\
\hline & 0 & 12,5 & 0 & 12,5 \\
\hline IRGA 417 & 86Aa & $76 \mathrm{Bb}$ & 97Aa & $89 \mathrm{Bb}$ \\
\hline Avaxi CL & 87Aa & $81 \mathrm{Ba}$ & 97Aa & $94 \mathrm{Ba}$ \\
\hline Inov CL & $85 \mathrm{Aa}$ & $73 \mathrm{Bb}$ & $96 \mathrm{Aa}$ & $86 \mathrm{Bb}$ \\
\hline IAS $12-9$ (Formosa) & 86Aa & $45 \mathrm{Bc}$ & 97Aa & $71 \mathrm{Bc}$ \\
\hline
\end{tabular}

Mean values for each variable followed by the same letter in the line did not differ between each other using the Tukey test, at a 5\% level of significance. *Values not significant for the analysed variables. 


\section{REFERENCES}

ALBUQUERQUE, J.R.T. et al. Crescimento inicial e tolerância de cultivares de pepino sob estresse salino. Revista Brasileira de Agricultura Irrigada, Fortaleza, v. 10, n.2, p. 486 - 495, 2016. Available from: <http://www.inovagri.org.br/revista/index.php/ rbai/article/view/355>. Accessed: Nov. 20, 2016. doi: 10.7127.

ASCH, F. et al. Leaf K/Na ratio predicts salinity induced yield loss in irrigated rice. Euphytica, v.113, p.109- 118, 2000.

BRASIL. Regras para análise de sementes. Brasília: MAPA/ ACS, 2009. 399p.

CARMONA, F. C de. et al. Salinidade da água e do solo e seus efeitos sobre o arroz irrigado no Rio Grande do Sul. Cachoerinha: Instituto Riograndense do Arroz. 2011. 56p. (Boletim técnico, 10).

CARMONA, F. C. Salinidade da água e do solo e seus efeitos sobre o arroz irrigado no Rio Grande do Sul. 2011. 132 f. Tese (Doutorado em Ciência do Solo) - Faculdade de Agronomia, Universidade Federal do Rio Grande do Sul. Porto Alegre, 2011.

CONAB. Séries Históricas. Companhia Nacional de Abastecimento, Brasília, 2016. Online. Available from: $<$ http:// www.conab.gov.br/conteudos.php? $\mathrm{a}=1252$ \&ordem $=$ produto $/ />$. Accessed: Dec. 07, 2016

CORREIA, K. G. et al. Crescimento, produção e características de fluorescência da clorofila a em amendoim sob condições de salinidade. Revista Ciência Agronômica, v.40, p.514-521, 2009. Available from: <http://ccarevista.ufc.br/seer/index.php/ ccarevista/article/view/542>. Accessed: Apr. 18, 2014.

CUI, H. et al. Effect of sodium chloride on the panicle and spikelet morphogenesis in rice. Japanese Journal of Crop Science, v.64 p.593-600, 1995.

DEUNER, C. et al. Viabilidade e atividade antioxidante de sementes de genótipos de feijão-miúdo submetidos ao estresse salino. Revista Brasileira de Sementes, v.33, p. 711-720. 2011.

FRAGA, T.I. et al. Flooded rice yield as affected by levels of water salinity in different stages of its cycle. Revista Brasileira de Ciência do Solo, v.34, p.175-182, 2010.

KALAMIAN, S. et al. Effect of water deficit at vegetative and reproductive growth stages in leafy and commercial hybrids at maize. Agricultural Research, v.5, n.3, p.38-53, 2006.

KHAN, M. H.; PANDA, S. K. Alterations in root lipid peroxidation and antioxidative responses in two rice cultivars under $\mathrm{NaCl}$-salinity stress. Acta Physiologiae Plantarum, v.30, n.1, p.81-89, 2008
KHATUN, S.; FLOWERS, T.J. The estimation of pollen viability in rice. Journal of Experimental Botany, v.46, p.151$154,1995$.

LEMES, E. S. et al. Produtividade, qualidade fisiológica e expressão isoenzimática de sementes de arroz submetidas à salinidade, Santa Maria, RS, 2013. In:VIII Congresso Brasileiro de Arroz Irrigado, 2013, Santa Maria, RS. Anais... Santa Maria, 2013. Available from: <http://www.cbai2013.com.br/cdonline/docs/trab8562-188. pdf//>. Accessed: Jan. 30, 2014

MAAS, E. V. et al. Salinity sensitivity of sorghum at three growth stages. Irrigation Science, v.7, n.1, p.1-11, 1986.

MACHADO, A. Programa de Análise Estatística - winstat 2, 2002. Available from: <http://www.ufpel.tche.br/ amachado/ winstat/software//>. Accessed: Oct. 15, 2010.

NAKAGAWA, J. Testes de vigor baseados no desempenho das plântulas. In: KRZYZANOWSKI, F.; et al.. (Ed.). Vigor de sementes: conceitos e testes. Londrina: ABRATES, 1999. Cap.2, p.2-24.

RODRIGUES, L. N. et al. Produção de arroz em condições de salinidade a partir de mudas formadas com e sem estresse salino. Revista Brasileira Engenharia de Agrícola e Ambiental, v.9, (Suplemento), p.95-100, 2005.

SANTIAGO, C. M. et al. ARROZ - 500 PERGUNTAS 500 RESPOSTAS. Brasilia: EMBRAPA, 2013. $2^{\text {a }}$ edição.

SOARES, M.M. et al. Estresse hídrico e salino em sementes de soja classificadas em diferentes tamanhos. Pesquisa Agropecuária Tropical, Goiânia, v.45, n. 4, p.370-378.

SOUZA, P. S. DE L et al. Qualidade física e fisiológica de sementes de quiabo (Abelmoschus esculentus (L.) Moench) produzidas em diferentes lâminas de água salina, Fortaleza, CE, 2014. In: II INOVAGRI International Meeting, 2014, Fortaleza, CE. Anais... Fortaleza, 2014. Available from: <http://www. bibliotekevirtual.org/simposios/II-INOVAGRI-2014/a033.pdf >. Accessed: Aug. 06, 2014.

SULTANA, N. et al. Effect of $\mathrm{NaCl}$ salinity on photosynthesis and dry matter accumulation in developing rice grains. Environmental and Experimental Botany, v.42, p.211-220, 1999.

TRAVASSOS, K. D. et al. Produção de aquênio do girassol irrigado com água salobra. Revista Brasileira de Engenharia Agrícola e Ambiental, v.15, n.4, p.371-376, 2011.

TAIZ, L.; ZEIGER, E. Fisiologia vegetal. Porto Alegre: ArtMed, 2013.5 ed. 